Research Article

\title{
Mechanical Characteristics of Steel Shear Keyed Joints in the Construction and Finished States
}

\author{
Yu Zou (iD) and Dong Xu \\ College of Civil Engineering, Tongji University, Shanghai 200092, China \\ Correspondence should be addressed to Yu Zou; zouyu028@163.com
}

Received 30 September 2021; Accepted 19 November 2021; Published 2 December 2021

Academic Editor: Claudio Mazzotti

Copyright ( $2021 \mathrm{Yu}$ Zou and Dong Xu. This is an open access article distributed under the Creative Commons Attribution License, which permits unrestricted use, distribution, and reproduction in any medium, provided the original work is properly cited.

\begin{abstract}
Joints that represent locations of discontinuity were the prominent factors affecting the overall behavior of precast segmental bridges. In this study, the steel shear key was designed, which was used to transmit the shear stress of the joints. To study the mechanical characteristics of the steel shear keyed joints in the construction and finished states, direct shear experiments and numerical analysis were carried out. The experimental results showed that the steel shear keyed joints had a high bearing capacity and good ductility. Under the action of confining stress, the joints relied on the mechanical occlusion between the steel keys to transmit the shear forces. When the load-displacement curve entered the horizontal stage, it can still bore large relative deformation, and the bearing capacity did not decrease. In the construction state, the inelastic deformation of the steel shear key should be used to control the design value of the temporary load. In the finished state, the bearing capacity of joints should be controlled by the direct shear strength of the steel shear key, which can be calculated according to the shear formula. The shear strength of the material and size of the steel shear key are the main factors affecting the bearing capacity of steel shear keyed joints.
\end{abstract}

\section{Introduction}

In recent years, many posttensioned precast concrete segmental bridges (PCSBs) have been constructed, resulting from the demand for an economical and safe design, fast, versatile, aesthetically pleasing, practical construction, and excellent serviceability $[1,2]$. Joints are the characteristics of the PCSB, which transfer the shear stress of the joint. But the reinforcement and concrete are discontinuous at the joints, which is the weak part of the structure [3-5]. Under the action of direct shear loading, the joints will have direct shear failure parallel to the joint section $[6,7]$. Therefore, it is necessary to study the mechanical properties and failure modes of the joints under different working conditions.

The conventional concrete keyed joint was the common type of segmental bridge. Up to now, scholars have done much scientific research on the mechanical properties and shear capacity of concrete keyed joints through theoretical analysis, numerical simulation, and experimental research. Buyukozturk et al. [6] believed that the shear strength and stiffness of dry concrete keyed joints would increase with the increase of confining stress. Experimental results of Rombach and Bridges [8] showed that the shear strength of the epoxied joints was $20 \%$ greater than that of the dry joints. The experimental results of Turmo et al. [9] and Jiang et al. [3] showed that steel fiber reinforced concrete (SFRC) can improve the ductility of concrete key joints. The experimental results of Smittakor et al. [10] showed that steel fiber could improve the shear resistance of concrete keyed joints. Gopal et al. [11] found that the shear bearing capacity of ultra-high-performance fiber reinforced concrete (UHPFRC) key joints increased significantly with the number of keys. Kim et al. [12] conducted direct shear experiments on the joints of ultra-high-performance concrete (UHPC) and concluded that the failure load gradually increased with the number of keys. Sangkhon and Pisitpaibool [13] conducted experimental studies on the geometric effect of the keys and found that the shear bearing capacity of the semicircular and triangular keys was better than that of the trapezoidal keys, but the semicircular and 
triangular keys were more prone to brittle failure. To sum up, many researchers have obtained abundant research results through a large number of theoretical and experimental studies to obtain the influence of different parameters on the mechanical properties of concrete keyed joints and improve the local mechanical properties of the joints. With the gradual popularization of accelerated bridge construction all around the world, a new joint type with effective transmission force, easy manufacture, convenient construction, easy quality control, and the low comprehensive cost is more needed, compared to the traditional concrete shear key.

This study designed a new shear key of segmental bridges, which was made by steel shear key sets. Compared with the traditional concrete keyed joints, the stress state and characteristics of steel shear keyed joints are significantly different. And there are few kinds of research on the stress characteristics, failure modes, and ultimate bearing capacity of steel shear keyed joints under different working conditions.

Direct shear experiment and nonlinear finite element analysis were used to study steel shear keyed joint's mechanical properties and failure modes under different working conditions. A nonlinear finite element model was established based on the short-term loading characteristics of steel shear keyed joints in the construction stage. The load-displacement curve of steel shear keyed joints showed obvious nonlinear variation law under temporary load with material nonlinearity, geometric nonlinearity, and contact nonlinearity. The inelastic deformation of steel shear keys controlled the design of temporary load. Direct shear experiments were carried out based on the stress characteristics of steel shear keyed joints in the finished stage. By using the shear formula, the shear resistance of steel shear keyed joints under direct shear failure is obviously less than that of test results. To avoid the need for nonlinear calculation, the shear bearing capacity of steel shear keyed joints should be designed according to the shear strength of steel. According to the research results of this paper, structure designers can easily obtain the capacity control values of different types of steel shear keys under different working conditions and choose a design value from these, which provides a calculation and guidance basis for the design and construction of steel shear keyed joints.

\section{Design of the Steel Shear Key}

The steel shear key (SSK) is a new joint type with a simple structure and convenient assembly. It is composed of a convex key and a concave key. The convex key comprises an anchor head and a tenon, and the concave key comprises an anchor head and a mortise, as shown in Figure 1(a). The convex and concave keys are embedded in part A and part B, respectively. Segmental construction involves multiple segments joint together by posttensioning, as shown in Figure 1(b).

Q235 steel was used for the steel shear key, in which the design value of shear strength was $100 \mathrm{MPa}$ [14]. The length and diameter of the tenon were $40 \mathrm{~mm}$, respectively. Both concave and convex keys adopted a square anchor head with a side length of $70 \mathrm{~mm}$ and a length of $90 \mathrm{~mm}$. A variable cross section was adopted in the middle of the anchor head to improve the mechanical interaction between steel shear keys and concrete. The geometric size and model are shown in Figure 2.

\section{Mechanical Characteristics of the Steel Shear Key}

In the finished state, the bearing capacity of joints was provided by the steel shear keys and friction. However, before the longitudinal prestressed tendons were tensioned, joints' bearing capacity only depended on the interaction between the convex key and concave key. So, the resistance contribution of steel shear keyed joints will change from the construction state to the finished state. The main difference lies in whether the longitudinal prestressed tendon was tensioned or not.

The steel shear keyed joints were composed of steel and concrete, whose material characteristics, material strength, and failure mode were different. The steel shear keyed joints will have different resistance values determined by the materials and the nonlinear ultimate bearing capacity of structures. Therefore, to facilitate the structural design and ensure the regular work of the steel shear keyed joints in the construction and finished states, there are some necessary works: the mechanical behavior of the steel shear keyed joints is studied in the construction and finished states; the control factors guiding the design and construction of steel shear keyed joints are obtained under different working conditions; the failure modes are studied under different working conditions, and the maximum bearing capacity under the corresponding conditions are determined.

\section{Experimental Tests}

4.1. Theoretical Calculation. In the finished state, the joints probably caused the direct shear failure. The direct shear capacity of the steel shear key can be calculated by the following formula:

$$
F=\tau \cdot A(\mathrm{kN})
$$

In this study, the shear strength design value of the steel key is $[\tau]=100 \mathrm{MPa}$, and the sectional area of the tenon $A=1256 \mathrm{~mm}^{2}$. It can be calculated that the shear capacity of the joints was $125.6 \mathrm{kN}$ in the finished state. And the shear strength of the material and the diameter of the tenon were the crucial factors affecting the shear capacity of the steel shear keyed joint.

\subsection{Experimental Program}

4.2.1. Design of the Specimens. Push-off specimens were used by Buyukozturk et al. [6], Zhou et al. [15], and Ahmed and Aziz [2] to study the shear behavior of joints in the finished state, as shown in Figure 3. HRB400 reinforcing bars with a diameter of $16 \mathrm{~mm}$ were used for constructional reinforcement. The position of the loading point was set with 


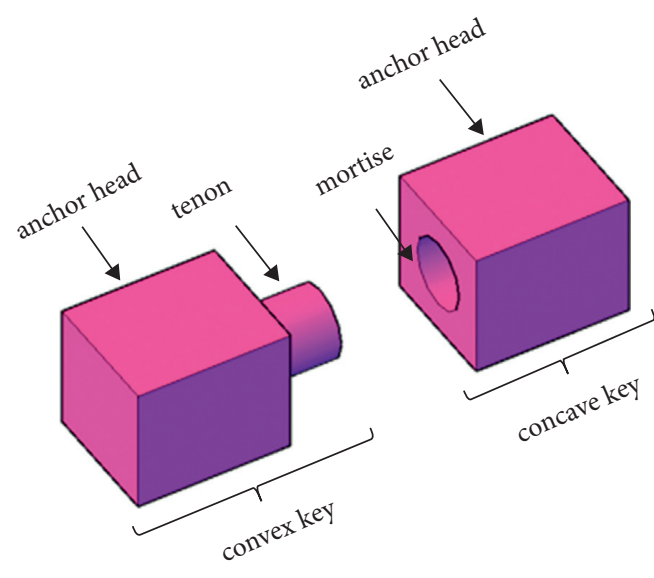

(a)

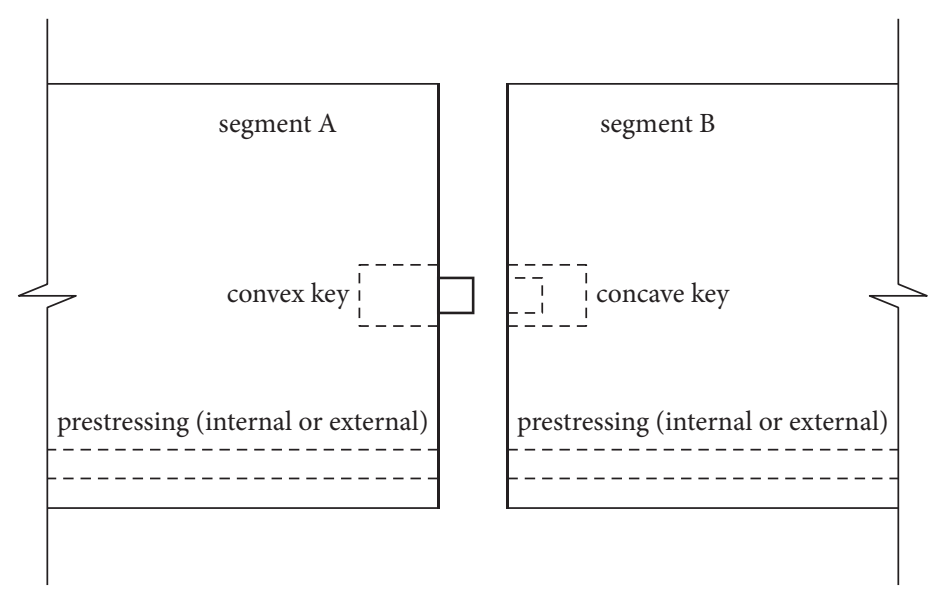

(b)

Figure 1: Schematic diagram of steel shear keyed joint. (a) Steel shear key and (b) assembly.
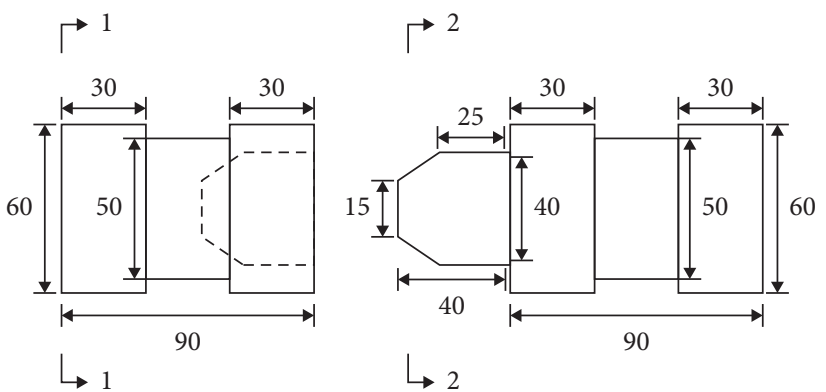

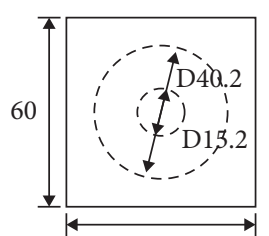

60

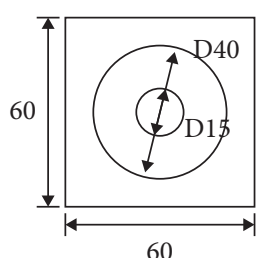

$2-2$

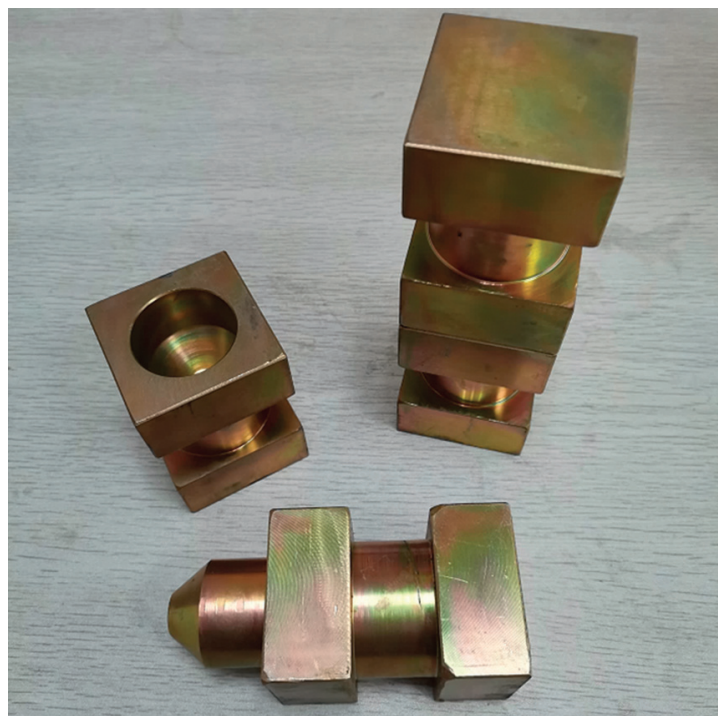

(b)

(a)

Figure 2: Design and model of the steel shear key. (a) Size and (b) model (unit: mm).

an embedded steel plate, which had the size of $200 \mathrm{~mm} \times 100 \mathrm{~mm} \times 25 \mathrm{~mm}$. The relative clearance of the specimen was $50 \mathrm{~mm}$. Two dry joint specimens were designed in this experiment. DS1 was the plate joint, and DS2 was the steel shear keyed joint. Table 1 presents these parameters of specimens.

4.2.2. Materials and Preparation of the Specimens. All specimens were made of C50 commercial normal concrete. Table 2 presents the concrete mix proportions and 28-day compressive strength. Match casting was adopted to prepare specimens, and the specimen models are shown in Figure 4.

4.2.3. Experimental Setup and Test Procedure. According to the experiments of Buyukozturk [6], Rombach and Bridges [8], and Koseki and Breen [16], the experimental setup and test procedure were designed, as shown in Figure 5. The test machine consisted of a steel frame, with a capacity of $1000 \mathrm{kN}$. The displacement-control tests for all specimens were conducted at a constant stroke rate of $0.1 \mathrm{~mm} / \mathrm{min}$ [3]. The confining stress system was composed of precise binding of rebar, horizontal loading plate, hydraulic jack, and load cell, and $1 \mathrm{MPa}$ confining stress was applied to all the specimens. The relative displacements between specimens were measured utilizing LVDTs. One vertical LVDT and two horizontal LVDTs were arranged on the front and back of the specimen. The experimental data were collected by using a ZFXIMP-1B dynamic acquisition instrument.

4.3. Test of DS1. Data of load-vertical displacement relationship are presented graphically in Figure 6, where the abscissa represents the relative vertical displacement, and the 

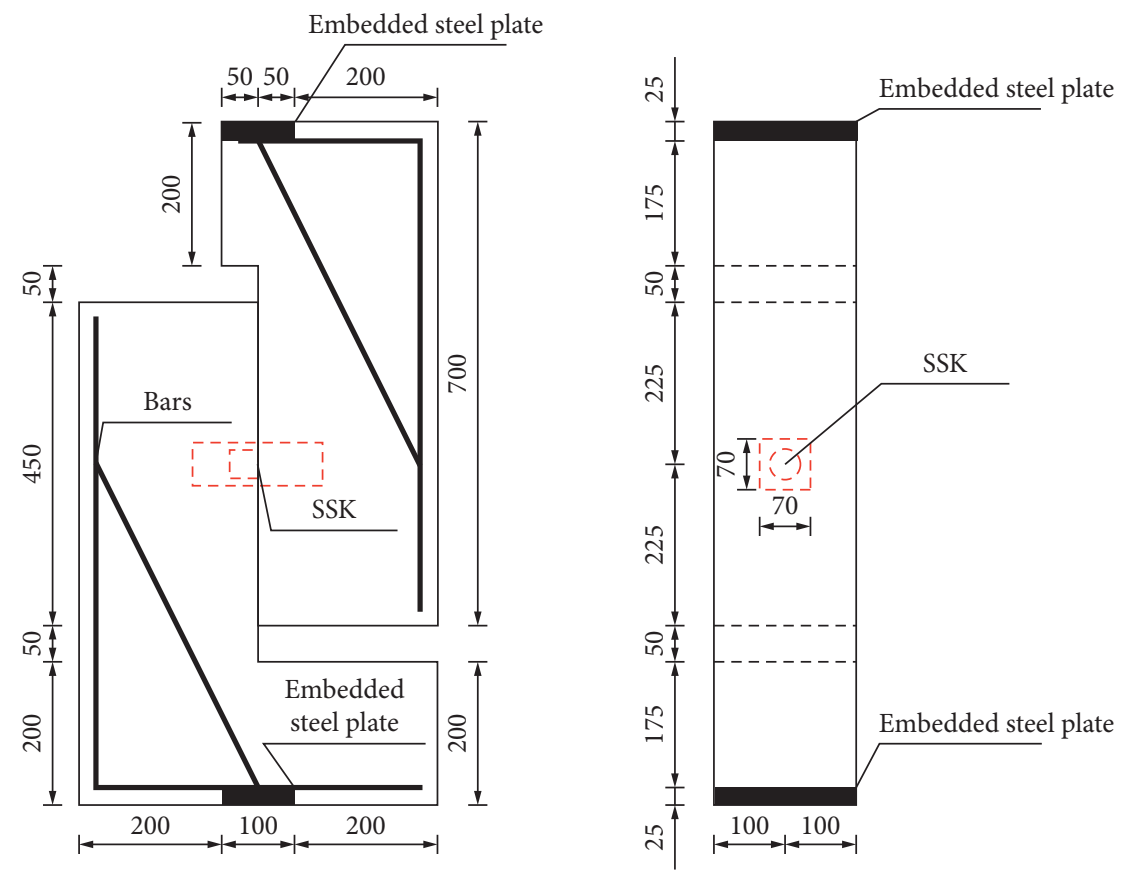

Figure 3: Geometric dimensions of specimen (unit: $\mathrm{mm}$ ).

TABle 1: Identification of the specimens and parameters.

\begin{tabular}{lcccccccc}
\hline Sequence number & SP ID & SSK type & Joint area $\left(\mathrm{mm}^{2}\right)$ & Joint types & Concrete & Number of SSKs & $\begin{array}{c}\text { Confining } \\
\text { stress (MPa) }\end{array}$ & $\begin{array}{c}\text { Number of } \\
\text { specimens }\end{array}$ \\
\hline 1 & DS1 & NO SSK & $200 \times 450$ & dry & C50 & 0 & 1 & 1 \\
2 & DS2 & SSK & $200 \times 450$ & dry & C50 & 1 & 1 \\
\hline
\end{tabular}

TABLE 2: Concrete mix proportions and 28-day compressive strength.

\begin{tabular}{lcccccccc}
\hline $\begin{array}{l}\text { Strength } \\
\text { grade }\end{array}$ & $\begin{array}{c}\text { Water } \\
\left(\mathrm{kg} / \mathrm{m}^{3}\right)\end{array}$ & $\begin{array}{c}\text { Cement } \\
\left(\mathrm{kg} / \mathrm{m}^{3}\right)\end{array}$ & $\begin{array}{c}\text { Mineral } \\
\text { powder } \\
\left(\mathrm{kg} / \mathrm{m}^{3}\right)\end{array}$ & $\begin{array}{c}\text { Fly ash } \\
\left(\mathrm{kg} / \mathrm{m}^{3}\right)\end{array}$ & $\begin{array}{c}\text { Sand } \\
\left(\mathrm{kg} / \mathrm{m}^{3}\right)\end{array}$ & $\begin{array}{c}\text { Coarse } \\
\text { aggregate } \\
\left(\mathrm{kg} / \mathrm{m}^{3}\right)\end{array}$ & $\begin{array}{c}\text { Admixture } \\
\left(\mathrm{kg} / \mathrm{m}^{3}\right)\end{array}$ & $\begin{array}{c}\text { Coarse aggregate } \\
\text { size }(\mathrm{mm})\end{array}$ \\
\hline C50 & 155 & 373 & 107 & 53 & 814 & 881 & 5.33 & $5-20$ \\
\hline
\end{tabular}

left-ordinate represents the vertical load. The most extensive loading force $F_{\max }=56.7 \mathrm{kN}$, and the joint static friction coefficient was calculated $\mu=0.63$. Jones [17] performed tests on dry joints; he concluded that the coefficient of friction approximated 0.39-0.69. Turmo et al. [9] recorded 0.491-0.577, and Koseki and Breen [16] measured 0.6. The curve is approximately linear to the loading force at which the joint surfaces commence slipping. No cracks were observed on the specimen, and the joint surfaces were not damaged except for small-scale griding, as evidenced by crushing concrete powder on the surface. The same phenomenon was found by Zhou et al. [15], Jones [17], and Buyukozturk et al. [6].

4.4. Test of DS2. Data of the load-vertical displacement relationship are presented graphically in Figure 7. The OA stage developed rigidly. When the loading force was $43.1 \mathrm{kN}$, the specimen began to have a relative vertical displacement.
As the loading progressed, the load-displacement curve entered the linear elastic stage. When the loading was $272.8 \mathrm{kN}$, two initial cracks appeared, as shown in Figures $8(\mathrm{a}) \sim 8(\mathrm{~b})$. One of the cracks was near horizontal, and the other was near a 45-degree angle. The horizontal crack and diagonal crack appeared on the front and back of the specimen at the same time, and the maximum crack width was greater than $0.2 \mathrm{~mm}$. Figure $8(\mathrm{c})$ shows the mechanical equilibrium of the convex key in the initial crack stage. After the specimen was cracked, the loadcarrying capacity of the joints dropped quickly, such as the BC stage.

As the loading continued, no new cracks appeared in the specimen. The diagonal crack gradually extended and steadily developed towards the loading point but did not cross the joint surface. The horizontal crack gradually developed together with the diagonal crack to form the main crack with an angle close to 45 degrees, and the width of the crack continued to increase. The crack propagation is shown in Figure 9. 




(a)

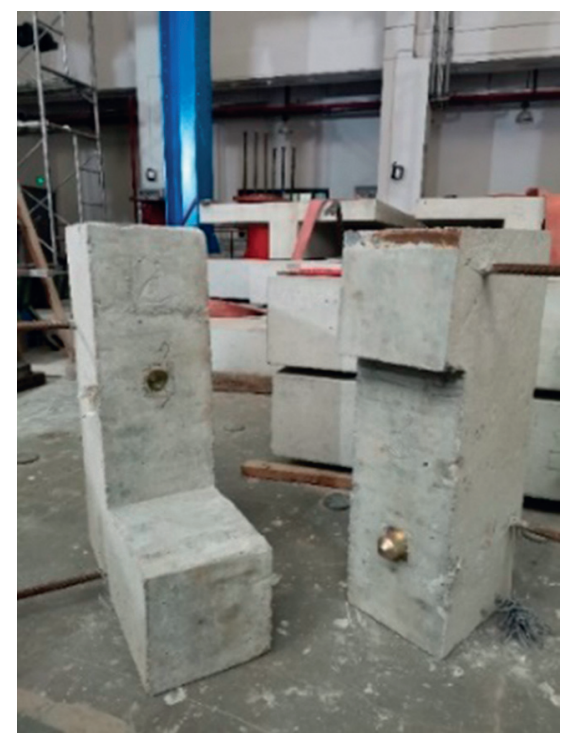

(b)

Figure 4: Experimental model. (a) DS1 and (b) DS2.



(a)

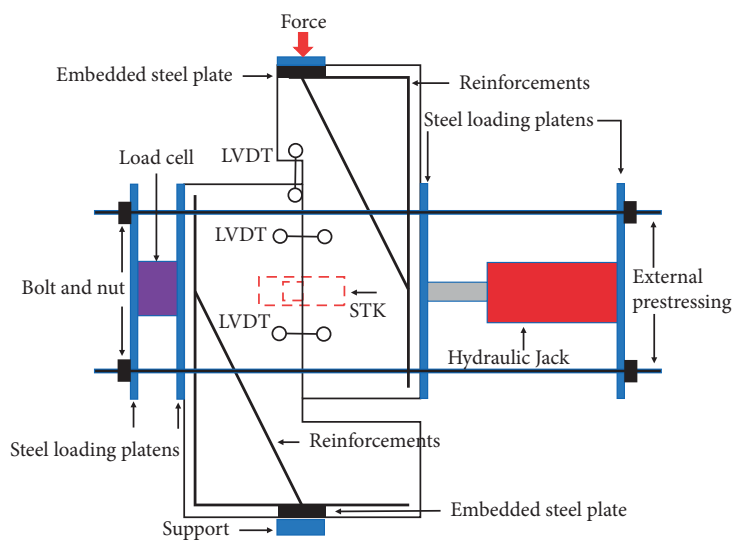

(b)

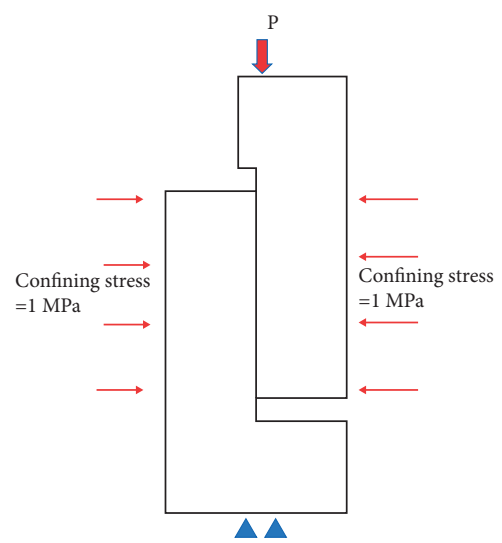

(c)

FIgURe 5: Test setup. (a) Test machine, (b) confining stress system, and (c) simplified mechanics.

According to the load-displacement curve of DS2, when the loading suddenly decreased, the specimen quickly realized the redistribution of internal force and reached a new force balance. Then the curve entered the strengthening stage CD, and the loading reached the peak load of $314.1 \mathrm{kN}$. As the loading continued, the convex key gradually formed a separate body along the main crack, as shown in Figure 10(a). The specimen formed a balanced system under the action of confining stress, as shown in Figure 10(b). The loading was relatively stable, and the load-displacement curve was developed in the horizontal stage, such as the DE stage.

The joints ended up severely damaged, as shown in Figure 11. The convex key formed a completely detached body along with the main crack, while the concave key had no crack or damage.

\section{Finite Element Analysis}

5.1. Stress State of Steel Shear Keyed Joints in the Construction State. Taking the balanced cantilever assembly construction as an example, the steel shear keyed joints experience three stress states in the construction process. State 1 is the initial butt joint of tenon and mortise, as shown in Figure 12(a); State 2 is the half butt joint of tenon and mortise, as shown in Figure 12(b); State 3 is the full butt joint of tenon and mortise, as shown in Figure 12(c). The tenon and mortise are circular cross sections; there is the randomness of the contact point in the assembly process. So, the upper edge of the tenon is selected as the loading point for the convenience of calculation. Figure 12(d) shows the mechanical simplification of steel shear keyed joints under the above three states. 




FIGURE 6: DS1 vertical load vs. relative vertical displacement.

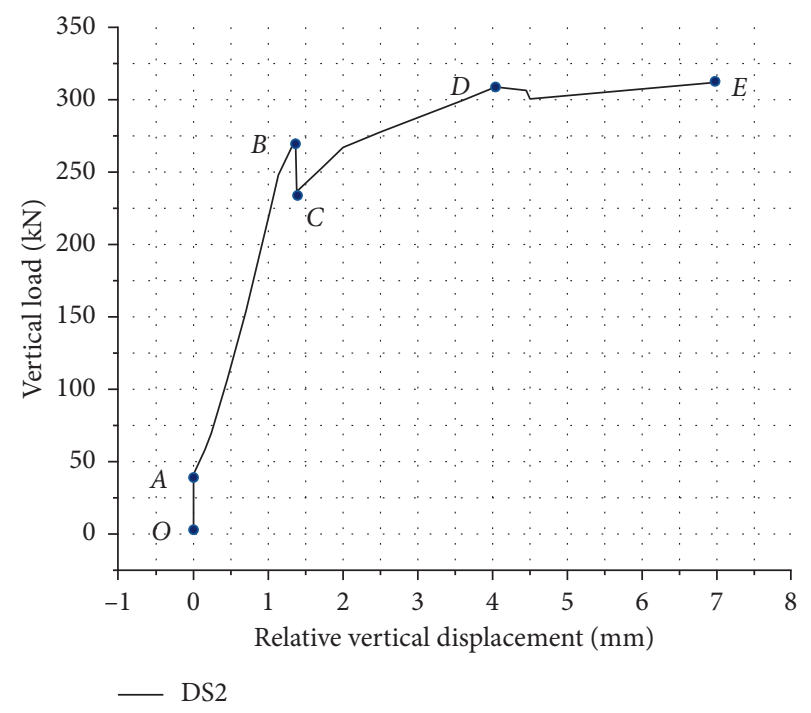

FIGURE 7: DS2 vertical load vs. relative vertical displacement.

5.2. Finite Element Model. The model used solid finite element analysis software Abaqus for the nonlinear calculation analysis. The geometric dimensions of the model are shown in Figure 13. The steel shear key is shown in Figure 2.

Tie constraints determined the contact relationship between the steel shear key and concrete members. The most critical area in which cracking happens was the castellated keyed area, where a more refined mesh with a nominal element size of approximately $5 \mathrm{~mm}$ was used, compared with a coarser mesh, with the nominal element size of approximately $20 \mathrm{~mm}$, that was used for the rest of the model [4]. In the model, the steel shear key and concrete were simulated by the three-dimensional eight-node reduced integration Lagrangian elements (C3D8R), with a total of 12,852 units. A fixed constraint was adopted on one side of the model. The most unfavorable State 1 (as shown in Figure $12(\mathrm{~d})$ ) was taken as the loading position of the model.
Displacement loading was adopted for the model. A displacement of $5 \mathrm{~mm}$ in the negative $Y$ direction was applied to the cantilever end of the tenon, and the coordinate system is shown in Figure 14. In the finite element analysis, geometric nonlinearity, material nonlinearity, and contact nonlinearity were considered. The material nonlinearity adopted the concrete damaged plasticity (CDP) model provided by Abaqus [18], and the constitutive relation of concrete (C50) was based on the specifications for the design of highway reinforced concrete and prestressed concrete bridges and culverts [14]. The finite element model is shown in Figure 14.

5.3. Nonlinear Whole Process Analysis. According to the stress characteristics of the members, the tenon is cantilever state, the anchor head, and nearby concrete contact compression. In the whole loading process, the failure of the steel shear key was determined by the $x$-direction stress, and $y$-direction stress determined the failure of concrete; the coordinate system is shown in Figure 14.

The calculation results were represented by the loaddisplacement curve, as shown in Figure 15. The OA stage was elastic. When the loading was $59.97 \mathrm{kN}$, the local yield of the tenon occurred at the loading point due to the stress concentration, and a yield platform appeared in the AB stage. At this time, the maximum compressive stress of concrete was 22.09 $\mathrm{MPa}$, and the maximum tensile stress of concrete was $1.268 \mathrm{MPa}$. The compressive and tensile yield strength of $\mathrm{C} 50$ was $32.4 \mathrm{MPa}$ and 2.65 $\mathrm{MPa}$ [14], respectively, and there was no concrete compressive or tensile yield.

When the loading was $92.01 \mathrm{kN}$, the tensile stress of the tenon was $235.2 \mathrm{MPa}$, which is greater than the standard tensile strength of $\sigma=235 \mathrm{MPa}$ (Q235) [14], and the vertical displacement of the tenon along with the $Y$ direction had occurred, as shown in point $\mathrm{D}$ of the loaddisplacement curve. With the increasing load, the inelastic vertical displacement of the tenon would occur. The inelastic displacement of the tenon would lead to the dislocation between the convex key and the concave key, which would affect the matching and assembly of the joints, especially in the multikeyed joints. To avoid the inelastic displacement of the tenon, the tensile yield loading of the tenon was taken as the control loading in the construction state. In this study, the tensile yield of the tenon was taken as the elastic limit failure mode under the short-term load condition, and the corresponding maximum bearing capacity was $92.01 \mathrm{kN}$. Figure 16 shows the tensile yield nephogram of the tenon. It can be considered that the loading at the tensile yield of the tenon was the ultimate bearing capacity under the shortterm load condition, which can be used to guide and control the temporary load in the construction state.

As the loading continued, the compression yield area of concrete gradually expanded. The joint reached the ultimate bearing capacity. When the maximum loading force was $97.23 \mathrm{kN}$, the loading suddenly decreased, as shown in point $\mathrm{E}$ of the load-displacement curve. At this time, the maximum tensile stress of the tenon was $249 \mathrm{MPa}$, which is greater than the standard tensile yield 


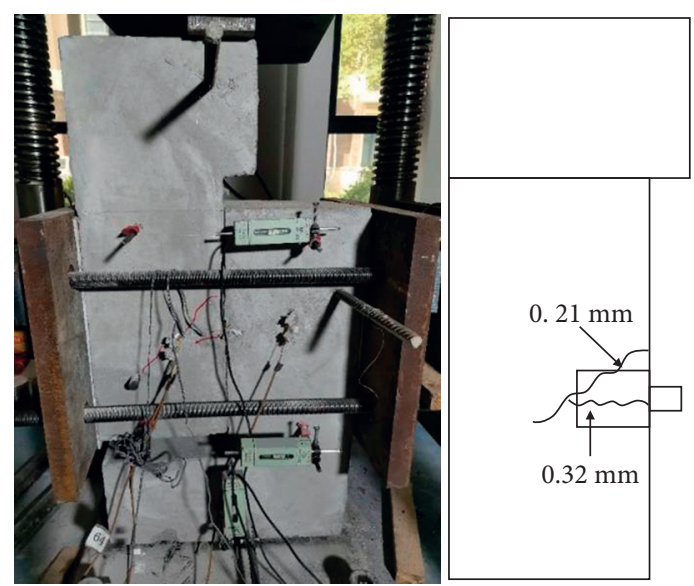

(a)

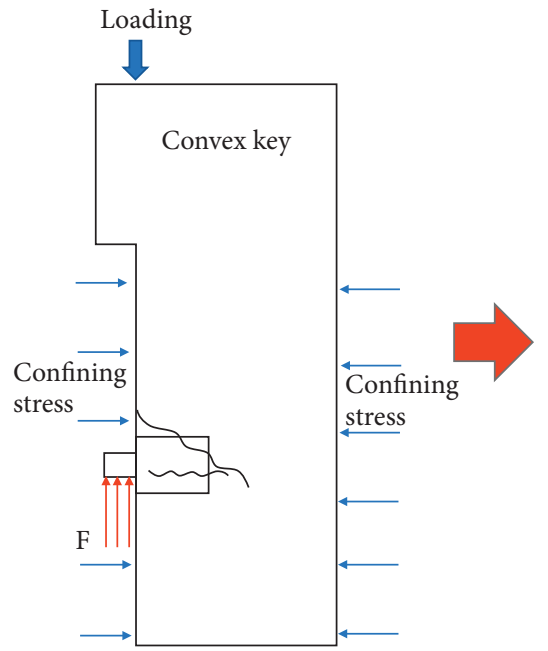

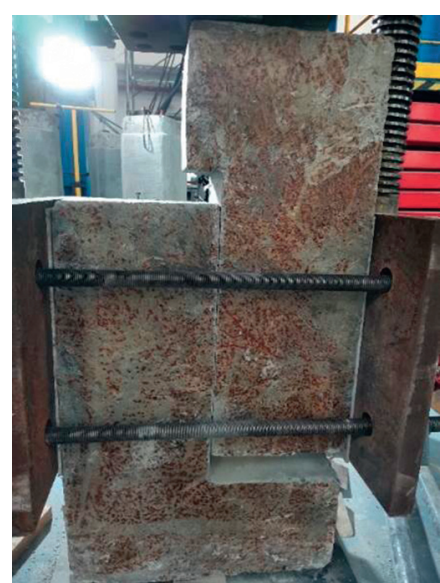

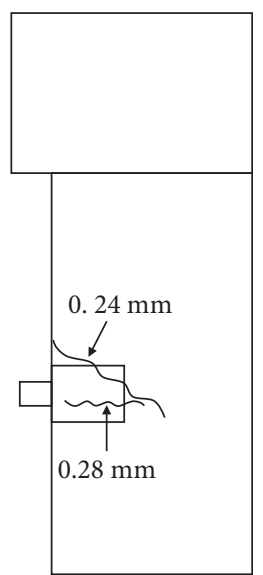

(b)
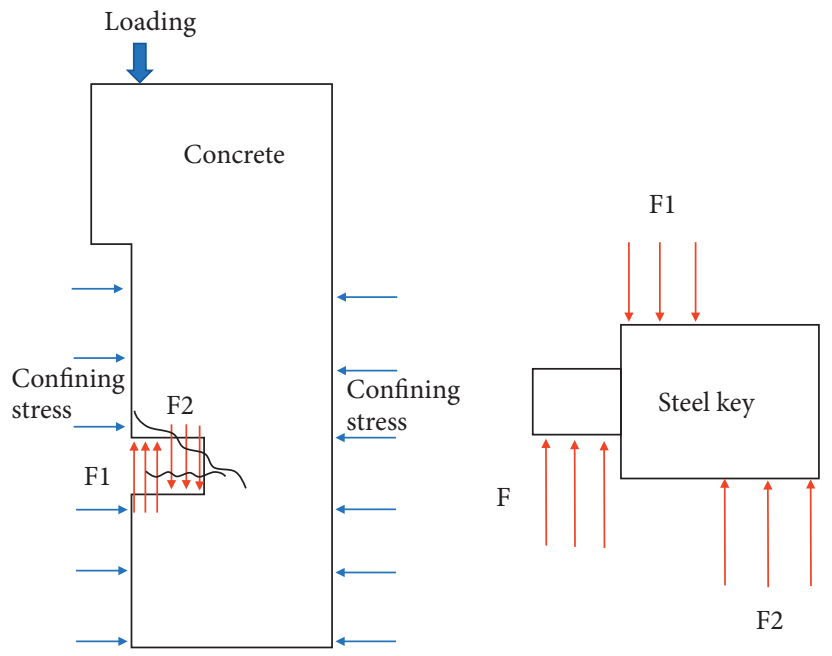

F2

(c)

FIgURE 8: Initial crack of DS2. (a) Section A, (b) section B, and (c) mechanical equilibrium model.



(a)

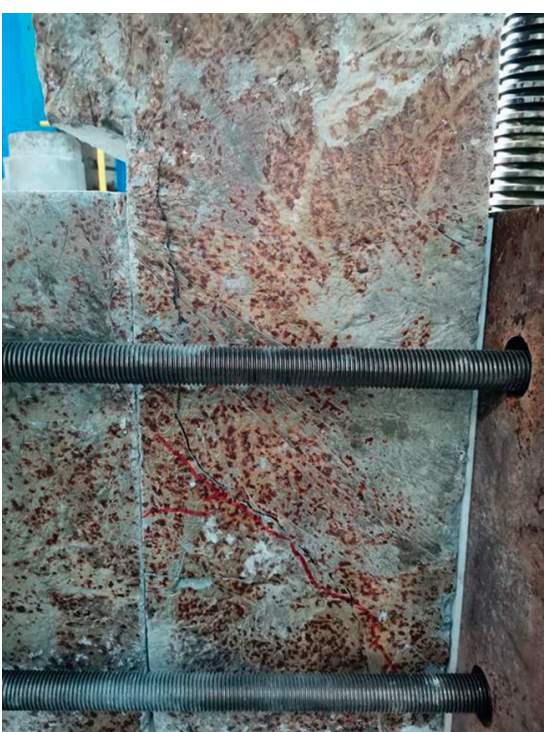

(b)

FIgURE 9: Crack propagation of DS2. (a) Section A and (b) section B. 


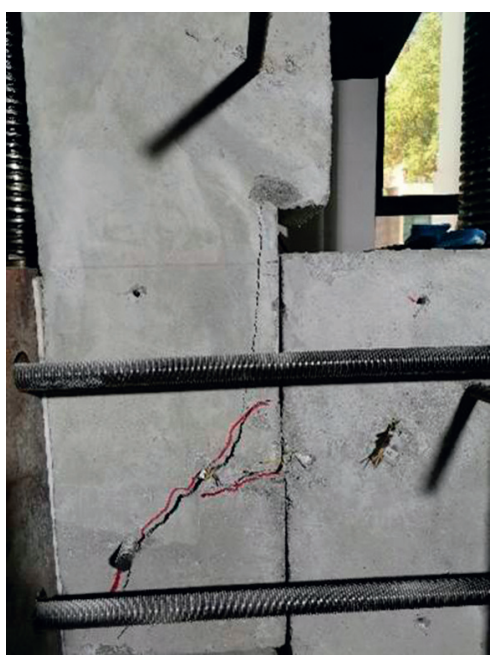

(a)


(b)

Figure 10: Failure state. (a) Failure mode and (b) mechanical diagram after specimen failure.

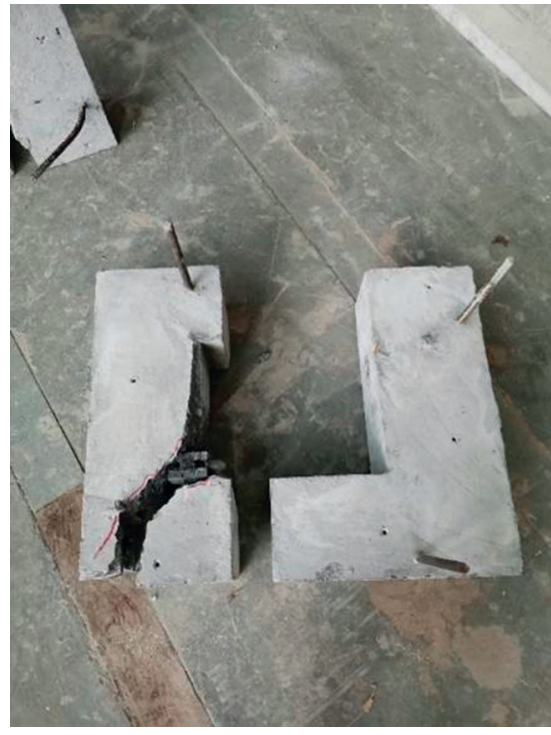

(a)

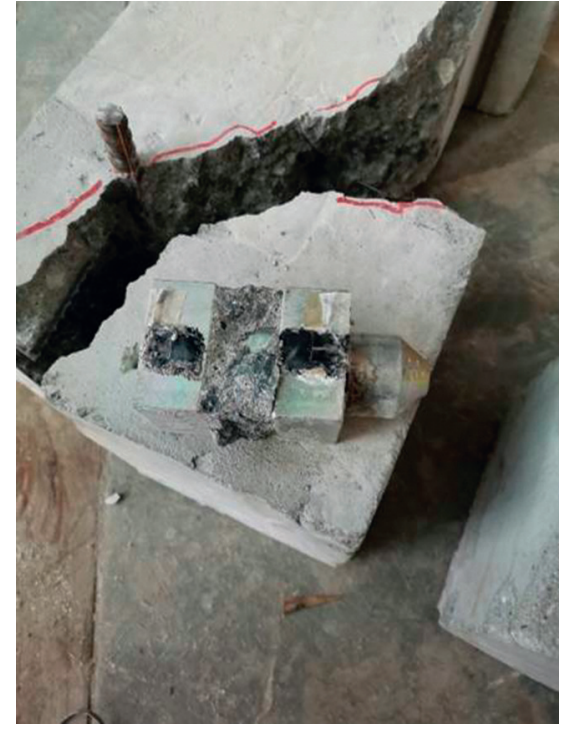

(b)

Figure 11: Failure mode of DS2. 


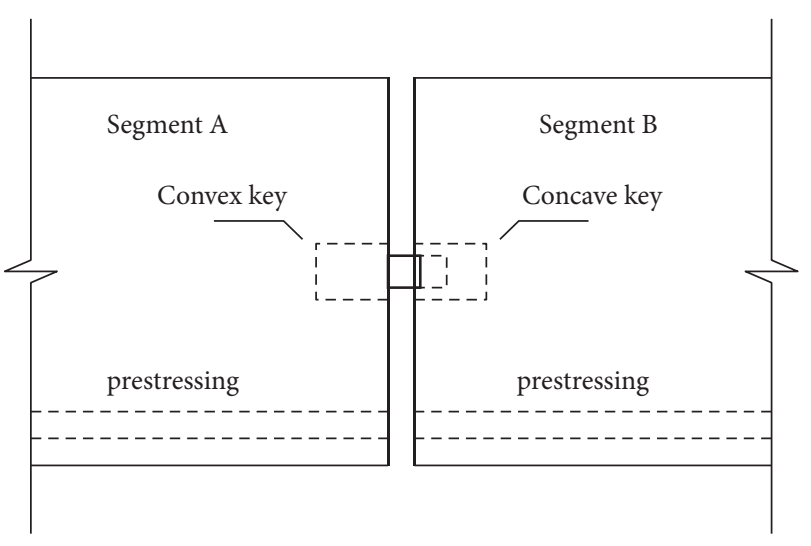

(a)



(c)

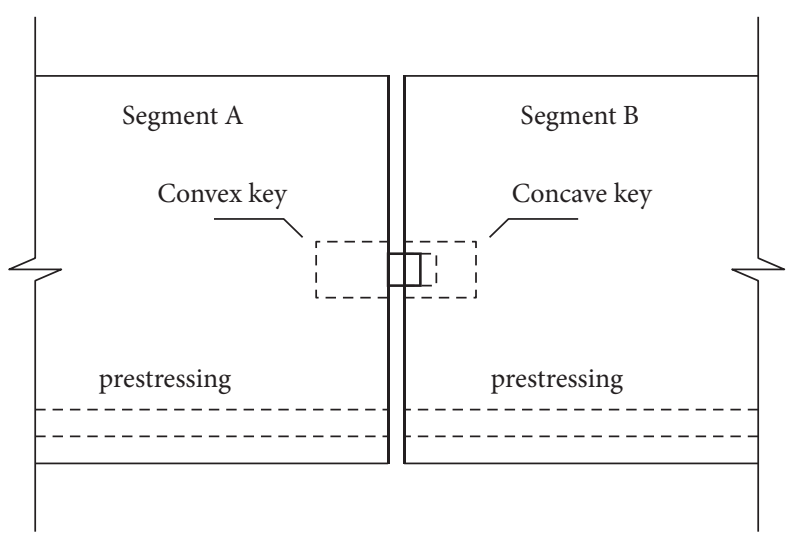

(b)
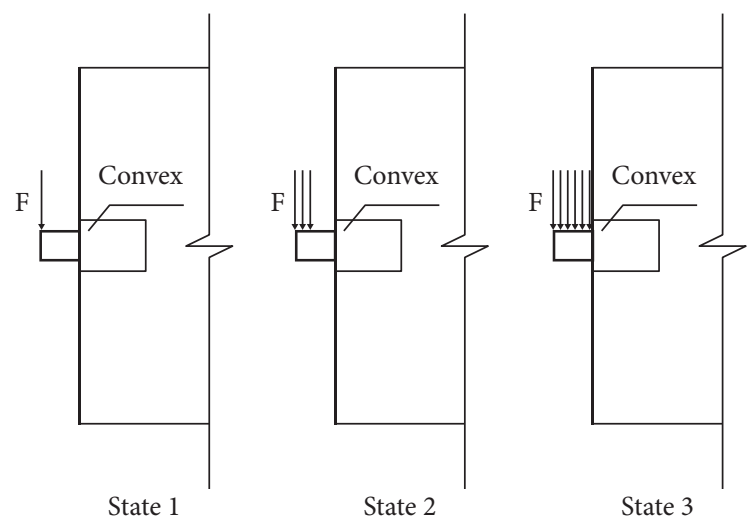

(d)

FiguRE 12: Stress state of steel shear keyed joints during construction process. (a) State 1: initial butt joint, (b) State 2: half butt joint, (c) State 3: full butt joint, and (d) simplified mechanics.

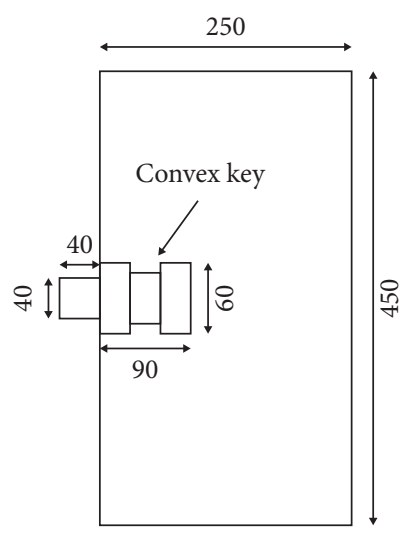

(a)

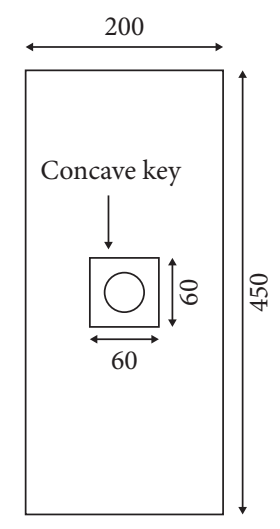

(b)

Figure 13: The geometric dimensions of model. (a) Elevation view and (b) section view (unit: mm).

strength $[\sigma]=235 \mathrm{MPa}[14]$. Therefore, the tensile yield of the tenon and compressive yield of the concrete can be considered as the nonlinear failure mode of the steel shear key joints under short-term load conditions. The steel shear key nonlinear ultimate bearing capacity was $97.23 \mathrm{kN}$, in the construction state. Under the nonlinear limit state of the concrete and steel shear key, the nephograms are shown in Figure 17. 


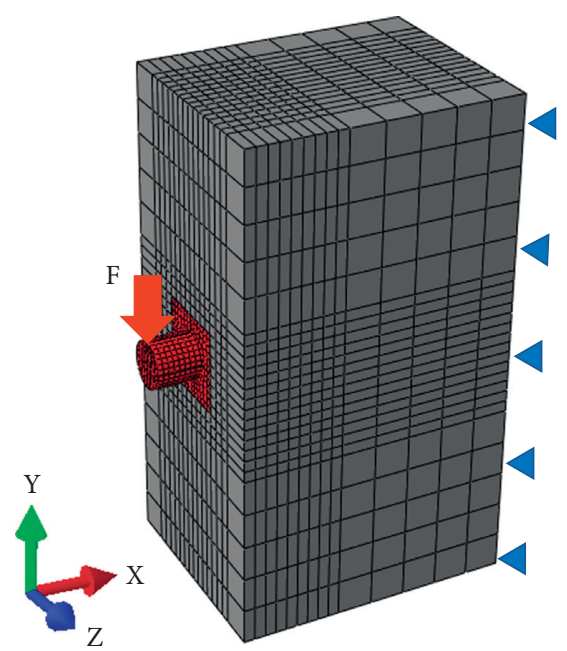

FIGURE 14: Finite element model of steel shear keyed joint in construction state.

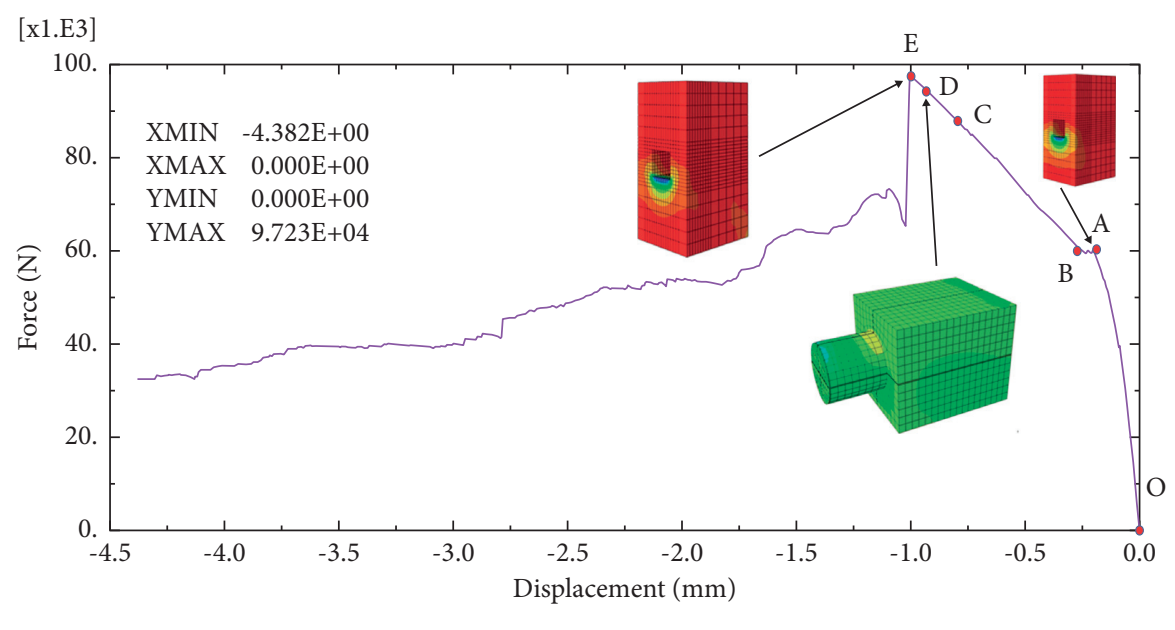

- RF-DIS

FIgURE 15: Mechanical behavior of steel shear key joint in construction state.

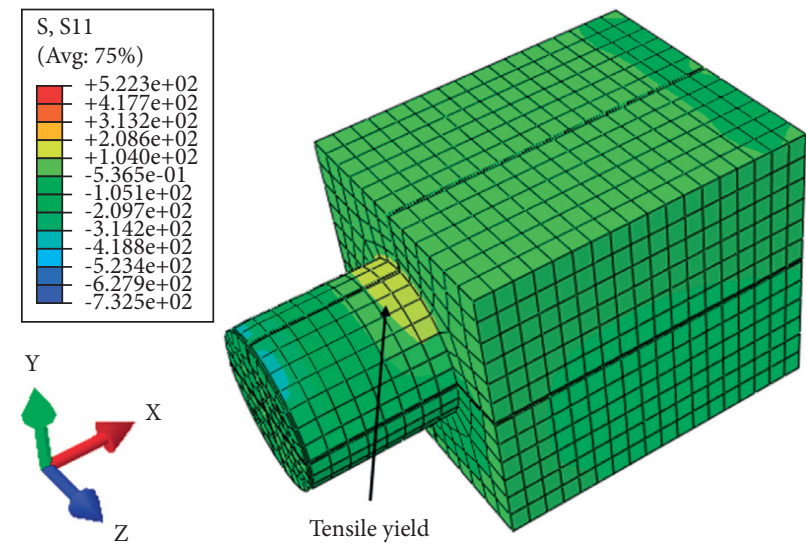

Figure 16: Stress nephogram of steel shear key. 


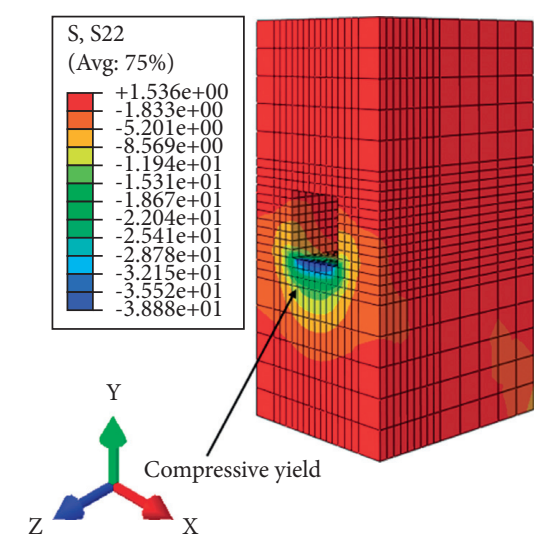

(a)

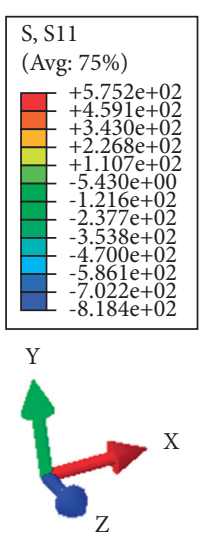



(b)

FIGURE 17: Stress nephogram of concrete and steel shear key in ultimate bearing capacity stage. (a) Stress nephogram of the concrete and (b) stress nephogram of the steel shear key.

TABle 3: Maximum bearing capacity of steel shear keyed joint under different working conditions.

\begin{tabular}{|c|c|c|c|c|c|}
\hline \multirow[t]{2}{*}{ Diameter of the tenon $(\mathrm{mm})$} & \multirow[t]{2}{*}{ Size of anchor head $(\mathrm{mm})$} & \multicolumn{2}{|c|}{ Construction state } & \multicolumn{2}{|c|}{ Finished state } \\
\hline & & Maximum bearin & capacity $(\mathrm{kN})$ & Maximum bea & ng capacity (kN) \\
\hline \multirow[t]{2}{*}{40} & $90 \times 60 \times 60$ & $\begin{array}{c}\text { Inelastic deformation } \\
\text { of steel shear key }\end{array}$ & $\begin{array}{l}\text { Ultimate bearing } \\
\text { capacity of } \\
\text { specimen }\end{array}$ & $\begin{array}{l}\text { Direct shear } \\
\text { failure of steel } \\
\text { shear key }\end{array}$ & $\begin{array}{l}\text { Ultimate bearing } \\
\text { capacity of } \\
\text { specimen }\end{array}$ \\
\hline & & 92.01 & 97.23 & 125.60 & 214.50 \\
\hline
\end{tabular}

\section{Resistance Calculation}

In the construction state, there were two failure modes of the steel shear key. The first one was the steel shear key occurred inelastic deformation. The second one was the steel shear key reached nonlinear ultimate strength. In this study, the corresponding load of the first failure was $92.01 \mathrm{kN}$; the corresponding load of the second failure was $97.23 \mathrm{~N}$. So, the design and construction were guided by the first failure mode and bearing capacity during the construction process.

In the finished state, there were two failure modes of the steel shear keyed joint. The first one was the steel key that caused the direct shear failure, and the shear formula calculated the resistance. In this study, the direct shear strength of the steel shear key was $125.6 \mathrm{kN}$. The second one was the steel shear key joints reached nonlinear ultimate strength. From the experimental phenomena of DS2, the width of initial cracks exceeded $0.2 \mathrm{~mm}$. The cracking load was the ultimate bearing capacity of DS2 $\left(F_{\max }=271.2 \mathrm{kN}\right)$. At the moment of cracking of DS2, the confining stress was $90 \mathrm{kN}$. According to the friction coefficient $(\mu=0.63)$ of DS1, the resistance provided by the friction surface was calculated to be $56.7 \mathrm{kN}$. The net resistance of the steel shear key was $F_{S}=214.5 \mathrm{kN}$. Therefore, according to the experimental results and finite element calculation, the maximum bearing capacity of the steel shear keyed joint under different working conditions is shown in Table 3.

\section{Conclusion}

(1) Based on experimental study and numerical analysis, the maximum bearing capacity of steel shear keyed joint is obtained under different control conditions in the construction and the finished stage, respectively.

(2) During the construction stage, the inelastic deformation of tenon should be used to control the temporary load design. In the service stage, the shear capacity of the joint should be controlled by the shear strength of steel. The shear capacity of steel shear keyed joints can be calculated according to the shear formula $(F=\tau \cdot A)$. The material and the diameter of the steel shear key are the critical factors affecting the bearing capacity of steel shear keyed joints.

(3) It is suggested that the control load of the inelastic deformation of the steel shear key should be used as resistance design and the direct shear strength of the steel shear key as the safety reserve.

(4) The steel shear keyed joints rely on the contact compression between steel and concrete to transfer the shear force under the confining stress. The joint has high shear bearing capacity and good ductility. When the load-displacement curve enters the horizontal stage, the bearing capacity does not decrease and can bear large relative deformation.

(5) In this paper, only two specimens and one finite element model were designed to analyze the mechanical properties of steel shear key joints during the construction and service stage. The subsequent research can be based on the force transmission mechanism, crack development, and failure mechanism of the steel shear key joint. 


\section{Data Availability}

Some or all data, models, or codes that support the findings of this study are available from the corresponding author upon reasonable request. (1. Finite element model; 2. Experimental data of test 1 and test 2).

\section{Conflicts of Interest}

The authors declare that there are no conflicts of interest regarding the publication of this study.

\section{Acknowledgments}

This research was sponsored by the National Natural Science Foundation of China (52078363).

\section{References}

[1] G. H. Ahmed and O. Q. Aziz, "Stresses, deformations and damages of various joints in precast concrete segmental box girder bridges subjected to direct shear loading," Engineering Structures, vol. 206, Article ID 110151, 2020.

[2] G. H. Ahmed and O. Q. Aziz, "Shear behavior of dry and epoxied joints in precast concrete segmental box girder bridges under direct shear loading," Engineering Structures, vol. 182, pp. 89-100, 2019.

[3] H. Jiang, R. Wei, Z. John Ma, Y. Li, and Y. Jing, "Shear strength of steel fiber-reinforced concrete dry joints in precast segmental bridges," Journal of Bridge Engineering, vol. 21, no. 11, Article ID 04016085, 2016.

[4] R. Shamass, X. Zhou, and G. Alfano, "Finite-element analysis of shear-off failure of keyed dry joints in precast concrete segmental bridges," Journal of Bridge Engineering, vol. 20, no. 6, Article ID 04014084, 2015.

[5] H. Jiang, L. Chen, Z. J. Ma, and W. Feng, "Shear behavior of dry joints with castellated keys in precast concrete segmental bridges," Journal of Bridge Engineering, vol. 20, no. 2, Article ID 04014062, 2015.

[6] O. Buyukozturk, M. M. Bakhoum, and S. Michael Beattie, "Shear behavior of joints in precast concrete segmental bridges," Journal of Structural Engineering, vol. 116, no. 12, pp. 3380-3401, 1990.

[7] M. A. Issa and H. A. Abdalla, "Structural behavior of single key joints in precast concrete segmental bridges," Journal of Bridge Engineering, vol. 12, no. 3, pp. 315-324, 2007.

[8] I. G. Rombach and S Bridges, "Precast segmental box girder bridges with external prestressing-design and construction," INSA Rennes Segmental Bridges, pp. 1-15, 2002.

[9] J. Turmo, G. Ramos, and A. C. Aparicio, "Shear strength of dry joints of concrete panels with and without steel fibres," Engineering Structures, vol. 28, no. 1, pp. 23-33, 2006.

[10] W. Smittakorn, P. Manavithayarak, and P. Sukmoung, "Improvement of shear capacity for precast segmental box girder dry joints by steel fiber and glass fiber," MATEC Web of Conferences, vol. 258, Article ID 04006, 2019.

[11] B. A. Gopal, F. Hejazi, M. Hafezolghorani, and V. Yen Lei, "Numerical analysis and experimental testing of ultra-high performance fibre reinforced concrete keyed dry and epoxy joints in precast segmental bridge girders," International Journal of Advanced Structural Engineering, vol. 11, no. 4, pp. 463-472, 2019.
[12] Y. Kim, W. Chin, and S. Jeon, "Interface shear strength at joints of ultra-high performance concrete structures," International Journal of Concrete Structures and Materials, vol. 12, no. 1, p. 59, 2018.

[13] A. Sangkhon and C. Pisitpaibool, "Shear strength test of joint with different geometric shapes of shear keys between segments of precast segmental bridge," International Transaction Journal of Engineering, Management, \& Applied Sciences \& Technologies, vol. 8, pp. 23-37, 2017.

[14] C. IsotPsRo, Specification for Design of Highway Reinforced Concrete and Prestressed Concrete Bridges and Culverts, China Communications Press, Beijing, China, 2018, (in Chinese).

[15] X. Zhou, N. Mickleborough, and Z Li, "Shear strength of joints in precast concrete segmental bridges," ACI Structural Journal, vol. 102, p. 3, 2005.

[16] K. Koseki and J Breen, Exploratory Study of Shear Strength of Joints for Precast Segmental Bridges, The University of Texas at Austin, Austin, TX, USA, 1983.

[17] L. L. Jones, "Shear test on joints between precast post-tensioned units," Magazine of Concrete Research, vol. 11, no. 31, pp. 25-30, 1959.

[18] D. Simulia, “Abaqus 6.11 Analysis User's Manual,” Abaqus 6.11Documentation, vol. 22, 2011. 